\title{
Lean manufacturing implementation in reducing waste for electronic assembly line
}

\author{
Nurul Husna Zakaria ${ }^{1,}$, Nik Mohd Zuki Nik Mohamed ${ }^{1,2}$, Mohd Fadzil Faisae Ab Rahid ${ }^{1}$, \\ and Ahmad Nasser Mohd Rose ${ }^{1}$ \\ ${ }^{1}$ Faculty of Mechanical Engineering, Universiti Malaysia Pahang, 26600 Pekan, Pahang, Malaysia. \\ ${ }^{2}$ Automotive Engineering Centre, Universiti Malaysia Pahang, 26600 Pekan, Pahang, Malaysia.
}

\begin{abstract}
Lean manufacturing is the most convenient way to eliminate unnecessary waste and can provide what customers demand. This paper presents possibilities and sustainability of application of lean manufacturing method by using a virtual simulation of the workers performance in a line production of small and medium industry. Actual case study and Witness simulation were used in this study to find the waste that exists in the production and identified the performance of workers in the production line. Lean manufacturing concept has identified and rectified problems related to low productivity in the assembly line. The case study is involved a line production for electronic part assembly. The result of this preliminary study should illustrate the relationship of worker's performance by lean manufacturing method as well as the productivity improvements which help to reduce cost for manufacturer. Lean manufacturing method has been used during the study to reduce the cost when waste is eliminated by reducing the workstation without reducing the performance of the production. The performance of the production is increased when allocating the labor in a needed working area. Lastly, the study also proves that the new layout has improved the process to be used for future production process.
\end{abstract}

\section{Introduction}

Lean manufacturing is a thinking that aims to remove and reduce wastes in each range of production counting the customer relations, supplier systems, product design, and plant management [1]. It can be implemented to remain competitive by aiding its clients in a better way and continually reducingcosts needed $[2,3]$.

Lean manufacturing concepts can be organized into three levels consist of lean manufacturing objectives and fundamental principles, prime management and manufacturing approaches and also the implementation techniques that are the actions for applying and maintaining the stratagems $[2,3]$. The orderly removal of waste will ease the cost of working the prolonged enterprises and satisfies the customer's need for supreme value at a lower cost [13]. In lean production or process, mistakes are continually made but

\footnotetext{
* Corresponding author: nhusnazakaria@gmail.com
} 
these faults are not usually repetitive since this is one of waste that the lean aim to exclude $[1,9]$.

\subsection{Benefits of lean manufacturing}

Some typical benefits that lean offers to the industries are financial saving, less rework, reduced lead-time, increased process understanding, less process waste and reduced inventory $[5,10]$. Based on a research that had been done in 200 SME companies, their perceptions toward lean benefits are cost saving, continuous improvement, waste reduction, tools and technique to improve production operation, fully integrated management philosophy, a way of life, comprehensive system of organizing and managing the supply chain and lastly is headcount reduction, which are shown in figure $1[16,14]$.

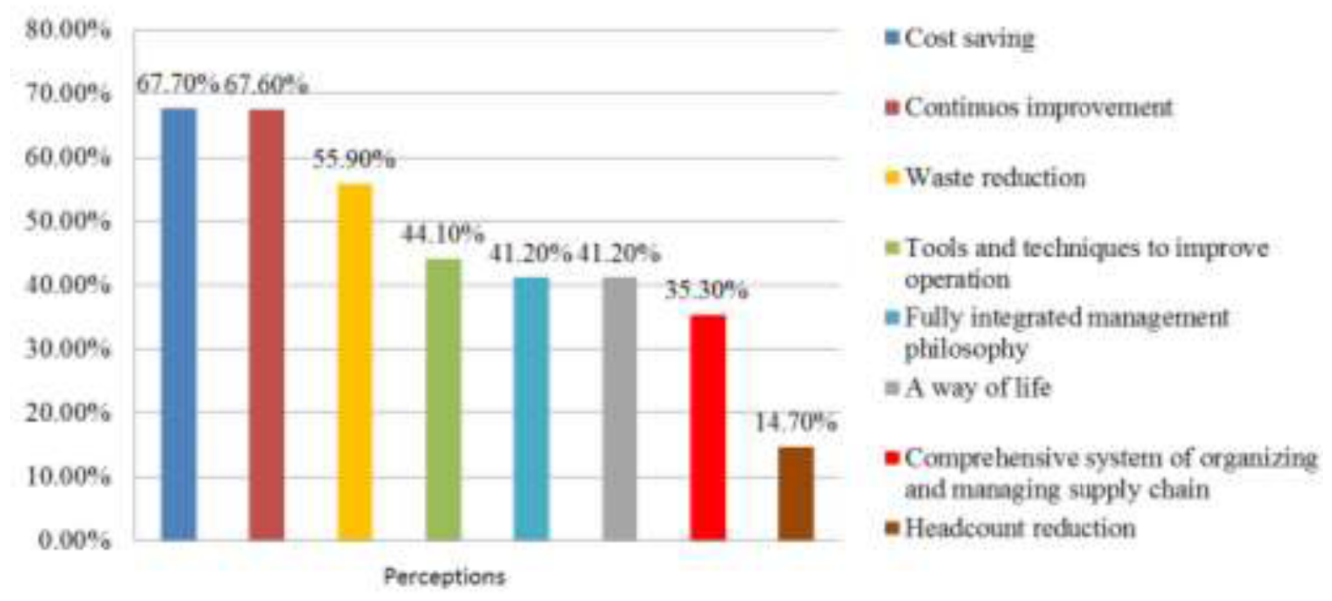

Fig. 1. Graph of perceptions towards lean practices.

\subsection{Methods in lean manufacturing}

A cluster of lean production methods is grouped into five categories. According to $[4,6,8,12,15]$, methods in these categories in Table 1 .

\subsection{Type of waste}

In Lean Manufacturing, there have seven types of waste targeted which is product defects, waiting time, processing waste, overproduction, motion waste, inventory, and transportation. In general, a basic understanding about these wastes is, a defect is a manufacture product that out of specification, and service components that cause in rework, scrap, checkup, flawed materials or replacement production. Waiting time means postponements allied with stock-outs, equipment downtime, machine breakdown, capacity bottlenecks and lot processing delays. Processing waste is processed phases that are not essential to manufacturing the product. Overproduction is more products being produced than demand and before it is needed. Motion waste is defined as a human motion that are pointless and work-in-process (WIP) moving extensive distances. Then, inventory is 
additional raw material, finished goods, or WIP, which contributes towards pending further processing, while transportation, waste means work done to transport unnecessary stock to a warehouse [1]. The types of waste are simplified in Table 2.

Table 1. Cluster of lean production methods.

\begin{tabular}{|c|c|}
\hline Type & Lean Method \\
\hline \multirow{5}{*}{ Machinery and equipment } & Low Cost Automation \\
\hline & Overall Equipment Effectiveness (OEE) \\
\hline & Preventive Maintenance \\
\hline & Single Minutes Exchange of Dies (SMED) \\
\hline & Total Productive Maintenance \\
\hline \multirow{7}{*}{ Material flow and layout } & Cellular Manufacturing \\
\hline & First in First Out (FIFO) \\
\hline & One-piece-flow \\
\hline & Simulation software \\
\hline & Optimization of the supply chain \\
\hline & Value Stream Mapping (VSM) \\
\hline & Workstation design \\
\hline \multirow{8}{*}{ Organization and staff } & $5 \mathrm{~S}$ \\
\hline & Autonomous work groups \\
\hline & Benchmarking \\
\hline & Ideas management \\
\hline & Job rotation \\
\hline & Lean office (Administration) \\
\hline & Kaizen \\
\hline & Standardization \\
\hline \multirow{3}{*}{ Quality } & FMEA \\
\hline & Poka Yoke \\
\hline & Quality Circles \\
\hline
\end{tabular}

This study will focused on material flow and layout type which is using simulation software method and workstation design in order to provide improvement for current production that met the objectives for the research which is to study the existing process in the company and to analyze the data by using the lean method, that lastly will provide a comparison of improved process to be a basis for future set up.

\section{Methodology}

In conducting this study, some methods are scheduled in details. This phase of activity is following Plan-Do-Check-Act (PDCA) method. After getting enough information in data collections, a gap analysis is proceeded to know the difference from the standard where steps needed to change from the current state to desire state or output is determined. Some visit is planned to complete things needed to do this project. 


\subsection{Observation and data collection}

The observation and data collection was made by having an interview session with the company supervisor and also their workers. Then another approach to get the data collections is by 'Genchi Genbutsu', go and understand the actual situation. Literally, by doing this approach, it helps to have a better understanding of current condition in the factory. Other than 'Genchi Genbutsu', Gemba is the other approach. It is a method of discovery deformity over observation and it aids to recognize main processes in production. Based on this, a process mapping is created by using material and information flow chart. According to the process mapping, by using material and information flow chart, any unnecessary waste or non-value added which hiding in the production can be detected. Other than that, problems that linked and related to material flow can be recognized and can produce a new improve layout. In creating a new layout, the simulation of it is designed by using Witness software.

Table 2. Type of waste.

\begin{tabular}{|c|l|}
\hline Types of Waste & \multicolumn{1}{c|}{ Descriptions } \\
\hline Product Defects & $\begin{array}{l}\text { Faults during the process that each demanding re-works or } \\
\text { supplementary work. }\end{array}$ \\
\hline Waiting Time & Tools or product pauses are a non-added value to the buyer. \\
\hline Processing Waste & $\begin{array}{l}\text { The situation of a particular process step that does not contribute any } \\
\text { benefit to the product. }\end{array}$ \\
\hline Over Production & $\begin{array}{l}\text { Product prepared without a specific client. } \\
\text { The progress of a product, a procedure or a production competence for } \\
\text { no added value. }\end{array}$ \\
\hline Motion Waste & $\begin{array}{l}\text { The unnecessary motion of the people who control the manufacturing } \\
\text { equipment is wasteful. Where they are in a movement that did not } \\
\text { support the manufacturing of the product. } \\
\text { An unnecessary motion of data, information, and decisions. }\end{array}$ \\
\hline Inventory & $\begin{array}{l}\text { Storage of products, intermediates, raw materials that will lead to cost } \\
\text { money. }\end{array}$ \\
\hline Transportation & $\begin{array}{l}\text { Transporting the product to numerous places. } \\
\text { While the product is in a movement, it is in a situation that will not be } \\
\text { processed and thus did not count values to the client. }\end{array}$ \\
\hline
\end{tabular}

\subsection{Applying lean method}

Once observation and identification are done, data that have been collected will be used to identify which method of lean is suitable to be implemented in the production area. This will be justified according to the seven elements of waste which occur in lean manufacturing.

\subsection{Simulation by using software}

The Witness simulation makes it possible to creating a variety of discrete and continuous elements. Subject on the type of component, each can be in any quantity of 'states' which means either idle, busy, blocked, in-setup, broken down, and waiting labor [7]. The end of 
the simulation done by using Witness software, the result from the data will be analyzed whether it brings any improvement towards the company.

\subsection{Data analysis}

The result obtained from simulation in Witness will be analyzed whether it brings any improvement towards the company and can be used for future setup.

\section{Results and discussion}

The first step in collecting the data in the focused cell is observed the layout in the production by detailing the sequences of workstation involved. Figure 2 below is the layout and process in the production.

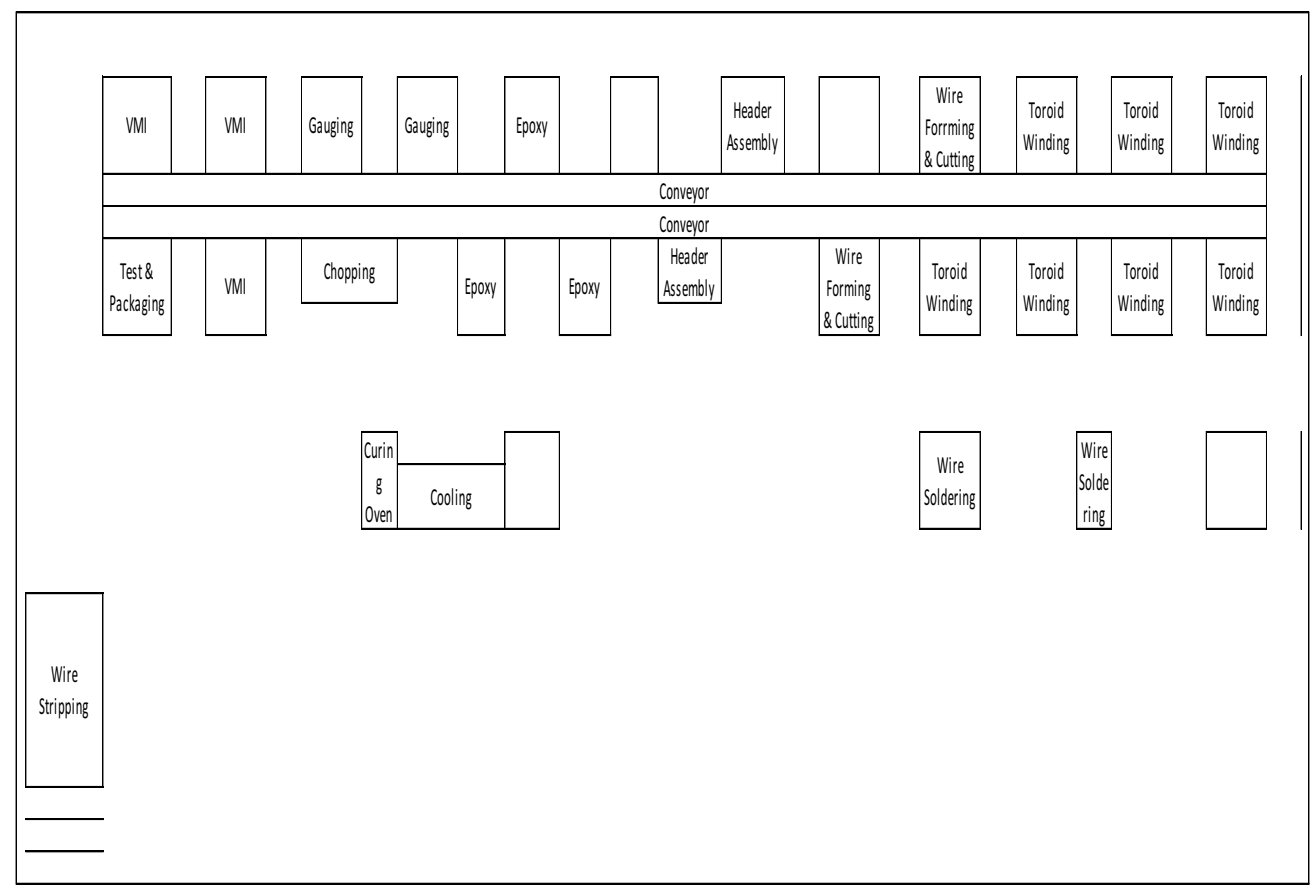

Fig. 2. Current layout in focused cell.

Other than observing the layout of the focused cell, the data involved in the production are being collected. Below is the type of data that has been tabulated in a Table 3 and 4 . The cycle time for each worker is taken three different session; morning, afternoon and evening, in order to get the average cycle time.

The performance for current production is run in software and the result of performance is shown in Table 5. According to the results of performance of each labor, it shows that Gauging Process has workers with a high percent of idleness. By referring to this result, an improved process can be made. 
Table 3. Data collections in existing production.

\begin{tabular}{|l|l|}
\hline \multicolumn{1}{|c|}{ Type of data } & \multicolumn{1}{c|}{ Time } \\
\hline Demand per day & 4000 \\
\hline Working Hours per day & 10 hours \\
\hline Break per day & 0.75 hours \\
\hline Available Working Hours per day & 9.25 hours \\
\hline Takt Time & 8.3 seconds \\
\hline Target per Hour & 433 \\
\hline Conveyor Speed $(\mathrm{m} / \mathrm{s})$ & 0.03 \\
\hline
\end{tabular}

Table 4. Cycle time for each worker.

\begin{tabular}{|c|c|c|c|c|c|}
\hline Workers & Process & $\begin{array}{c}\text { Cycle } \\
\text { time 1 (s) }\end{array}$ & $\begin{array}{c}\text { Cycle } \\
\text { time 2 (s) }\end{array}$ & $\begin{array}{c}\text { Cycle } \\
\text { time 3 (s) }\end{array}$ & $\begin{array}{c}\text { Avg. } \\
\text { Cycle } \\
\text { Time (s) }\end{array}$ \\
\hline 1 & Wire Soldering & 59 & 58 & 46 & 54.3 \\
\hline 2 & Wire Soldering & 60 & 58 & 48 & 55.3 \\
\hline 3 & Toroid Winding & 99 & 99 & 86 & 95 \\
\hline 4 & Toroid Winding & 56 & 55 & 58 & 56.3 \\
\hline 5 & Toroid Winding & 67 & 64 & 68 & 66 \\
\hline 6 & Toroid Winding & 92 & 91 & 89 & 91 \\
\hline 7 & Toroid Winding & 62 & 65 & 64 & 63.7 \\
\hline 8 & Toroid Winding & 34 & 29 & 31 & 31.3 \\
\hline 9 & Toroid Winding & 40 & 38 & 39 & 39 \\
\hline 10 & Wire Forming \& Cutting & 12 & 10 & 11 & 11 \\
\hline 11 & Wire Forming \& Cutting & 13 & 12 & 13 & 12.7 \\
\hline 12 & Header Assembly & 13 & 15 & 14 & 14 \\
\hline 13 & Header Assembly & 7 & 8 & 7 & 7.3 \\
\hline 14 & Epoxy & 40 & 37 & 37 & 38 \\
\hline 15 & Epoxy & 40 & 30 & 30 & 33.3 \\
\hline 16 & Epoxy & 24 & 22 & 22 & 22.7 \\
\hline 17 & Chopping & 3 & 3 & 3 & 3 \\
\hline 18 & Gauging & 4 & 5 & 4 & 4.7 \\
\hline 19 & Gauging & 2 & 2 & 2 & 2 \\
\hline 20 & VMI & 5 & 15 & 7 & 9 \\
\hline 21 & VMI & 13 & 15 & 14 & 14 \\
\hline 22 & VMI & 31 & 27 & 28 & 28.7 \\
\hline 23 & Test \& Packaging & 6 & 5 & 5 & 5.3 \\
\hline
\end{tabular}

\subsection{Data analysis for first improvement}

Based on existing data, an improved process is produced to be one of the future setups for this company. The method used to create an improved process is by referring to the percentage of the idleness of the labors in existing production where it is found that two labors that are in the gauging process have a high percent of idleness compared to others. According to that, one workstation is reduced, and the performance of it is being analyzed by using Witness. The two labor of Gauging Process in current production has been reduced to one labor, which means the workstation is reduced from 23 to 22 . Lady18 is chosen to be removed because she has the highest percent of idleness that is $93.84 \%$. After 
the workstation has been removed, based on the performance in Table 6, the labor's performance did not have any different except for Lady17, which is $85.53 \%$ of idleness reduce to 71.05 since she handles the process that had been removed from Lady18. The performance calculation of this improvement is shown by Eq. (1).

$$
\text { Performance }=\frac{(1041 \text { piece } / 288 \mathrm{~min})}{7 \text { piece per } \min } \times 100=51.64 \%
$$

Table 5. Result of performance by using Witness.

\begin{tabular}{|c|c|c|c|c|c|c|}
\hline Job Element & Name & $\%$ Busy & $\%$ Idle & $\begin{array}{c}\text { No. Jobs } \\
\text { Started }\end{array}$ & $\begin{array}{l}\text { No. Jobs } \\
\text { Ended }\end{array}$ & $\begin{array}{l}\text { Avg Job } \\
\text { Time (s) }\end{array}$ \\
\hline \multirow{2}{*}{ Wire Soldering } & Lady01 & 99.87 & 0.13 & 334 & 333 & 54.3 \\
\hline & Lady02 & 99.78 & 0.22 & 327 & 326 & 55.3 \\
\hline \multirow{7}{*}{ Toroid Winding } & Guy01 & 99.57 & 0.43 & 238 & 237 & 75.53 \\
\hline & Guy02 & 99.57 & 0.43 & 380 & 379 & 47.53 \\
\hline & Guy03 & 99.57 & 0.43 & 406 & 405 & 44.39 \\
\hline & Lady03 & 99.48 & 0.52 & 351 & 350 & 51.5 \\
\hline & Guy04 & 99.48 & 0.52 & 374 & 373 & 48.22 \\
\hline & Guy05 & 99.48 & 0.52 & 704 & 703 & 25.61 \\
\hline & Lady12 & 99.48 & 0.52 & 820 & 819 & 21.97 \\
\hline \multirow{2}{*}{$\begin{array}{l}\text { Wire Forming \& } \\
\quad \text { Cutting }\end{array}$} & Lady04 & 78.03 & 21.97 & 684 & 683 & 20.7 \\
\hline & Lady13 & 99.24 & 0.76 & 621 & 620 & 29 \\
\hline \multirow{2}{*}{ Header Assembly } & Lady05 & 99.05 & 0.95 & 2565 & 2564 & 7 \\
\hline & Lady14 & 51.61 & 48.39 & 1282 & 1281 & 7.3 \\
\hline \multirow{3}{*}{ Epoxy } & Lady06 & 89.45 & 10.55 & 427 & 426 & 38 \\
\hline & Lady16 & 78.33 & 21.67 & 427 & 426 & 33.3 \\
\hline & Lady07 & 53.49 & 46.51 & 427 & 427 & 22.7 \\
\hline Chopping & Lady09 & 18.48 & 81.52 & 1116 & 1116 & 3 \\
\hline \multirow{2}{*}{ Gauging } & Lady17 & 14.47 & 85.53 & 558 & 558 & 4.7 \\
\hline & Lady 18 & 6.16 & 93.84 & 558 & 558 & 2 \\
\hline \multirow{3}{*}{ VMI } & Lady19 & 55.43 & 44.57 & 1116 & 1116 & 9 \\
\hline & Lady10 & 85.7 & 14.3 & 501 & 500 & 31 \\
\hline & Lady20 & 85.75 & 14.25 & 542 & 541 & 28.7 \\
\hline Test \& Packaging & Lady11 & 13.21 & 86.79 & 1041 & 1041 & 2.3 \\
\hline
\end{tabular}

Statistics for the number of job ended in Table 6 did not have any changes even the workstation had been reduced and it shows that the output is same as current production. This shows that it is significant to reduce the workstation since the performance of it is equal to the performance of the current production. 
Table 6. Data on labors performance for first improvement.

\begin{tabular}{|c|c|c|c|c|c|c|}
\hline Job Element & Name & $\%$ Busy & $\%$ Idle & $\begin{array}{c}\text { No. Of } \\
\text { Jobs } \\
\text { Started }\end{array}$ & $\begin{array}{c}\text { No. Of } \\
\text { Jobs } \\
\text { Ended }\end{array}$ & $\begin{array}{c}\text { Avg Job } \\
\text { Time }\end{array}$ \\
\hline \multirow{2}{*}{ Wire Soldering } & Lady01 & 99.87 & 0.13 & 334 & 333 & 54.3 \\
\hline & Lady02 & 99.78 & 0.22 & 327 & 326 & 55.3 \\
\hline \multirow{7}{*}{$\begin{array}{l}\text { Toroidal } \\
\text { Winding }\end{array}$} & Guy01 & 99.57 & 0.43 & 238 & 237 & 75.53 \\
\hline & Guy02 & 99.57 & 0.43 & 380 & 379 & 47.47 \\
\hline & Guy03 & 99.57 & 0.43 & 406 & 405 & 44.39 \\
\hline & Lady03 & 99.48 & 0.52 & 351 & 350 & 51.5 \\
\hline & Guy04 & 99.48 & 0.52 & 374 & 373 & 48.22 \\
\hline & Guy05 & 99.48 & 0.52 & 704 & 703 & 25.61 \\
\hline & Lady12 & 99.48 & 0.52 & 820 & 819 & 21.97 \\
\hline \multirow{2}{*}{$\begin{array}{l}\text { Wire Forming } \\
\text { and Cutting }\end{array}$} & Lady04 & 78.03 & 21.97 & 684 & 683 & 20.7 \\
\hline & Lady13 & 99.24 & 0.76 & 621 & 620 & 29 \\
\hline \multirow{2}{*}{$\begin{array}{c}\text { Header } \\
\text { Assembly }\end{array}$} & Lady05 & 99.05 & 0.95 & 2565 & 2564 & 7 \\
\hline & Lady14 & 51.61 & 48.39 & 1282 & 1281 & 7.3 \\
\hline \multirow{3}{*}{ Epoxy } & Lady06 & 89.45 & 10.55 & 427 & 426 & 38 \\
\hline & Lady16 & 78.32 & 21.68 & 427 & 426 & 33.3 \\
\hline & Lady07 & 53.49 & 46.51 & 427 & 427 & 22.7 \\
\hline Chopping & Lady09 & 18.48 & 81.52 & 1116 & 1116 & 3 \\
\hline Gauging & Lady17 & 28.95 & 71.05 & 1116 & 1116 & 4.7 \\
\hline \multirow{3}{*}{ VMI } & Lady19 & 55.43 & 44.57 & 1116 & 1116 & 9 \\
\hline & Lady10 & 85.7 & 14.3 & 501 & 500 & 31 \\
\hline & Lady 20 & 85.75 & 14.25 & 542 & 541 & 28.7 \\
\hline $\begin{array}{c}\text { Test \& } \\
\text { Packaging }\end{array}$ & Lady11 & 13.21 & 86.79 & 1041 & 1041 & 2.3 \\
\hline
\end{tabular}

\subsection{Data analysis of second improvement}

A reallocating method is used in this second improvement by reallocating the free labor to a workstation that has a bottleneck which has a low capacity of buffer. The final improvement that gives increment in productivity when the labor is put into that process is by reallocating the labor to VMI process, since this process can be considered as final process before test and packaging stage. The analysis for this second improvement gives increment in productivity of the production, which is from 1041 total output it becomes 1109. The productivity for this improvement is calculated below.

$$
\text { Performance }=\frac{(1109 \text { pieces } / 288 \mathrm{~min})}{7 \text { piece permin }} \times 100=55.01 \%
$$


Below is the labors performance for second improvement where it shows that the output gained in this improvement is increased a bit. This output can be seen in number of job ended in the final process in Table 7, which in test and packaging stage.

Table 7. Data on labors performance for second improved process

\begin{tabular}{|c|c|c|c|c|c|c|}
\hline Job Element & Name & \% Busy & $\%$ Idle & $\begin{array}{c}\text { No. Of } \\
\text { Jobs } \\
\text { Started }\end{array}$ & $\begin{array}{c}\text { No. Of } \\
\text { Jobs } \\
\text { Ended }\end{array}$ & $\begin{array}{l}\text { Avg } \\
\text { Job } \\
\text { Time }\end{array}$ \\
\hline \multirow{2}{*}{ Wire Soldering } & Lady0 1 & 99.87 & 0.13 & 334 & 333 & 54.3 \\
\hline & Lady02 & 99.78 & 0.22 & 327 & 326 & 55.3 \\
\hline \multirow{7}{*}{ Toroidal Winding } & Guy01 & 99.57 & 0.43 & 238 & 237 & 75.53 \\
\hline & Guy02 & 99.57 & 0.43 & 380 & 379 & 47.53 \\
\hline & Guy03 & 99.57 & 0.43 & 406 & 405 & 44.39 \\
\hline & Lady03 & 99.48 & 0.52 & 351 & 350 & 51.5 \\
\hline & Guy04 & 99.48 & 0.52 & 374 & 373 & 48.22 \\
\hline & Guy05 & 99.48 & 0.52 & 704 & 703 & 25.61 \\
\hline & Lady12 & 99.48 & 0.52 & 820 & 819 & 21.97 \\
\hline \multirow{2}{*}{$\begin{array}{l}\text { Wire Forming and } \\
\text { Cutting }\end{array}$} & Lady04 & 78.03 & 21.97 & 684 & 683 & 20.7 \\
\hline & Lady13 & 99.24 & 0.76 & 621 & 620 & 29 \\
\hline \multirow{2}{*}{ Header Assembly } & Lady05 & 99.05 & 0.95 & 2565 & 2564 & 7 \\
\hline & Lady14 & 51.61 & 48.39 & 1282 & 1281 & 7.3 \\
\hline \multirow{3}{*}{ Epoxy } & Lady06 & 89.45 & 10.55 & 427 & 426 & 38 \\
\hline & Lady16 & 78.33 & 21.67 & 427 & 426 & 33.3 \\
\hline & Lady07 & 53.49 & 46.51 & 427 & 427 & 22.7 \\
\hline Chopping & Lady09 & 18.48 & 81.52 & 1116 & 1116 & 3 \\
\hline Gauging & Lady17 & 28.95 & 71.05 & 1116 & 1116 & 4.7 \\
\hline \multirow{4}{*}{ VMI } & Lady 18 & 55.43 & 44.57 & 1116 & 1116 & 9 \\
\hline & Lady19 & 68.66 & 31.34 & 434 & 433 & 28.7 \\
\hline & Lady 10 & 75.35 & 24.65 & 370 & 369 & 37 \\
\hline & Lady 20 & 70.61 & 29.39 & 310 & 309 & 41.4 \\
\hline Test \& Packaging & Lady11 & 14.08 & 85.92 & 1110 & 1109 & 2.3 \\
\hline
\end{tabular}

\section{Conclusions}

In this paper, it was aimed to reduce the waste exist in line production that related by the performance of workers in line. The virtual simulation was simulated based on data collections gained during observation process. The significant of each improvement was verified according to simulation result in the software used which the performance of 
production was calculated to support the result. The performance was reduced from $56.04 \%$ to $55.01 \%$ with total production from 1041 to 1109 pieces. According to the results obtained, the waste that had been addressed by this simulation is processing waste; a situation of a particular process step that does not contribute any benefit to the product where the two labors in one process are having a small percent of busy. In addition, with this improvement, the productivity of it is increased, since one of the bottlenecks of the production is solved.

\section{References}

1. Hicks, B. J. Lean information management: Understanding and eliminating waste. International Journal of Information Management. 27(4), 233-249, (2007)

2. Lewis, M. A., Lean Production and Sustainable Competitive Advantage, International Journal of Operation and Production Management. 20(0),121-125, (2000)

3. Matt, D. T., and Rauch, E. Implementation of Lean Production in Small Sized Enterprises. Procedia CIRP. 12(0), 420-425, (2013)

4. Mehta, R. K, Mehta, D., Mehta, and N. K.,. Lean Manufacturing Practices: Problems and Prospects. ANNALS. 3(0), 119-124, (2013)

5. Melton, T. The Benefits of Lean Manufacturing: What Lean Thinking has to Offer the Process Industries. Chemical Engineering Research and Design, 83(6), 662-673, (2005)

6. Ojaghi, Y., Khademi, A., Yusof, N. M., Renani, N. G., and Hassan, S. A. H. b. S, Production Layout Optimization for Small and Medium Scale Food Industry. Procedia CIRP. 26(0), 247-251, (2015)

7. Pam, L. M., and Michael, H. M.,, Witness Simulation Software A Flexible Suite of Simulation Tools. Proceedings of the 1997 Winter Simulation Conference. 17(0), 711717, (1997)

8. Raja, M. I. Lean Manufacturing-an Integrated Socio-Technical Systems Approach to Work Design. Clemson University. 5(0) 35-43, (2011)

9. Relkar, A. S., and Nandurkar, K. N. Optimizing \&amp; Analysing Overall Equipment Effectiveness (OEE) Through Design of Experiments (DOE). Procedia Engineering. 38(0) 2973-2980, (2012)

10. Rose, A.M.N., Deros, B.Md., Rahman, M.N.Ab. and Nordin, N. Lean manufacturing best practices in SMEs, Proceedings of the 2011 International Conference on Industrial Engineering and Operations Management. 2(5) 872-877, (2011)

11. Ulutas, B., and Islier, A. A. Dynamic facility layout problem in footwear industry. Journal of Manufacturing Systems. 36(0) 55-61, (2015)

12. Villa, A., and Taurino, T. From JIT to Seru, for a Production as Lean as Possible. Procedia Engineering. 63(0) 956-965, (2013)

13. Wahab, A. N. A., Mukhtar, M., and Sulaiman, R.. A Conceptual Model of Lean Manufacturing Dimensions. Procedia Technology. 11(0) 1292-1298, (2013)

14. Womack, JamesP., Jones, and DanielT, Lean Thinking: Banish Waste and Create Wealth In Your Corporation, Simon \& Schuster, New York. 45(0) 457-470, (1996)

15. Yu, C. W., Kuan, Y. W., and.Anwar A., A study on lean manufacturing implementation in the Malaysia electrical and electronics industry. European Journal of Scientific Research. 38(4) 521-535, (2009)

16. Zhou, B., Lean principle, practices, and impacts: a study on small and medium-sized enterprises (SMEs). Springer Science Business Media LLC. 10(0) 112-117, (2012) 